\title{
QUALITY OF BLACK SCORPIONFISH (Scorpaena porcus, Linnaeus 1758) MEAT COOKED IN DIFFERENT COOKING MATERIALS
}

\author{
Bengünur Çorapcı* \\ Sinop University, Faculty of Fishery, Department of Fish Processing Technology, \\ Sinop, Turkey
}

Received / Geliş: 12.08.2021; Accepted / Kabul: 12.11.2021; Published online / Online bask1: 16.11.2021

Çorapcr, B. (2021). Quality of black scorpionfish (Scorpaena porcus, Linnaeus 1758) meat cooked in different cooking materials. GIDA (2021) 46 (6) 1415-1424 doi: 10.15237/gida.GD21115.

Çorapc1, B. (2021). Farklı pişirme materyalleri içinde pişirilen iskorpit balığı (Scorpaena porcus, Linnaeus 1758) etinin kalitesi. GIDA (2021) 46 (6) 1415-1424 doi: 10.15237/gida.GD21115.

\begin{abstract}
This study aimed to investigate the effect of different cooking materials on some physical, nutritional, and sensory characteristics of black scorpionfish (Scorpaena porcus) meat. To achieve this aim, scorpion fish fillets were divided into four groups as open-roasted (control), oven bag cooked (Group A), baking paper wrapped (Group B) and aluminum foil wrapped (Group C). All fillets were cooked in an electrical oven. The nutritional and amino acid composition, water activity and color measurements were carried out in all samples including raw fish. Sensorial properties of all cooked samples were also evaluated. On comparing the raw and cooked groups it was found that cooking materials had a considerable effect on the nutritional and amino acid composition. The protein and total amino acid contents of the Control group were higher than that of the other groups due to water loss. It was also determined that the aromatic amino acid content of the control group was higher than the other groups. The cooking losses varied according to the type of cooking material. The method of cooking in the baking paper can be said to be the most preferable method for this fish according to the sensory analysis results.
\end{abstract}

Keywords: Scorpionfish, amino acids, aluminum foil, baking paper, oven bag

\section{FARKLI PİŞİRME MATERYALLERİ İÇİNDE PİŞİRİLEN İSKORPİT BALIĞI (Scorpaena porcus, Linnaeus 1758) ETİNİN KALİTESİ}

\section{ÖZ}

Bu çalışmanın amacı farklı pişirme materyallerinin iskorpit balığı eti üzerindeki bazı fiziksel, besinsel ve duyusal özelliklerine etkisini araştırmaktır. Bu amaçla iskorpit balığı filetoları üzeri açık pişirme (kontrol), firın poşetinde pişirme (A), yağlı kâğıtta pişirme (B), alüminyum folyoda pişirme (C) şeklinde dört gruba ayrılmıştır. Bütün filetolar elektrikli fırında pişirilmiştir. Besin ve aminoasit kompozisyonu, su aktivitesi ve renk ölçümleri çiğ balı̆ğ da içeren tüm örneklerde gerçekleştirilmiştir. Pişirilen tüm örneklerde duyusal özellikler de değerlendirilmiştir. Çĭ̆ ve pişmiş gruplar karşılaştırıldığında pişirme materyallerinin besin kompozisyonu ve aminoasit kompozisyonunu önemli ölçüde etkilediği bulunmuştur. Kontrol grubunun protein ve toplam aminoasit içeriği su kaybı nedeniyle diğer gruplardan yüksek bulunmuştur. Bununla birlikte, kontrol grubunun amino asit içeriği incelendiğinde aromatik amino asitlerin diğer gruplardan yüksek olduğu belirlenmiştir. Pişirme kayb1

\footnotetext{
${ }^{*}$ Corresponding author / Yazışmalardan sorumlu yazar

(1): bengucorapci@hotmail.com

(ग): (+90) $3682876265 / 3213$

鸟: (+90) 3682876268
}

Bengünur Çorapcı; ORCID no: 0000-0002-1005-5406 
pişirme materyalinin çeşidine göre değişiklik göstermiştir. Duyusal analiz sonuçlarına göre yağlı kâğıtta pişirme metodunun bu balık için en çok tercih edilen yöntem olduğu söylenebilir.

Anahtar kelimeler: İskorpit balığı, amino asit, alüminyum folyo, yağlı kâğıt, firın poşeti

\section{INTRODUCTION}

Scorpionfish (Scorpaena porcus L. 1758) is a demersal fish species belonging to the Scorpaenidae family. It is generally observed at rocky habitats and also seen at muddy and sandy sea bottoms, spending most of its time waiting for prey (Love et al., 1987). It is economically important for its delicious meat (Turk Culha, et al., 2016). According to TUIK, an average of 250.1 tons per annum of scorpionfish was reported to be caught on between 2008 and 2017 (TUIK, 2019). The blackscorpion fish is caught in the Black Sea in almost every fishing season (Kaya and Kocatepe, 2014).

Foods such as red meat and fish become more eatable and more digestible when they are subjected to cooking. However, cooking can lead to unacceptable changes, such as the loss of the nutritional value of foods, mainly due to lipid deterioration, and changes in some constituents of the protein (Uran ve Gokoglu, 2014). The basic function of protein in nutrition is to provide sufficient amounts of required amino acids. The protein quality is associated with amino acids components, the ratios of essential amino acids, and the physiological utilization of amino acids after digestion, assimilation, and oxidization (Friedman, 1996). The E/NE ratio is an indicator of high-quality protein. The essential amino acids of raw scorpionfish constitute approximately $52 \%$ of the total amino acids. The ratio of essential/non-essential amino acids (E/NE) has been reported as 1.08 (Kaya and Kocatepe, 2014).

Usually, cooking methods are divided into three sections. These methods can be listed as dry-heat, moist-heat, and combination-heat. Dry-heat methods cook the foods using hot air or fat. Examples of these methods are frying (pan or deep), grilling, roasting, and baking. The moistheat cooking methods cook the food with a liquid, usually water. For example, poaching, boiling and steaming, etc. The combination cooking methods use a combination of dry- and moist-heat methods (Moradi et al., 2011). When the studies on fish cooking methods are examined, it is usually seen that grilling, baking, frying (Tokur, 2007; Cheung et al., 2016) were used. The objective of this study was to investigate the effect of different cooking materials on some of the physicochemical, nutritional, and sensory properties of black scorpionfish meat.

\section{MATERIALS AND METHODS}

\section{Raw material}

Black scorpionfish (Scorpaena porcus) were purchased (as fish fillet) from a fisherman in the region of Sinop-Middle Black Sea. In total, $2.5 \mathrm{~kg}$ of scorpionfish fillets (skinless) were used in this study. They were transferred to the laboratory and were washed in iced water a few times.

\section{Methods}

\section{Grouping and Cooking Methods}

The scorpionfish fillets were split into four groups (413.20 $\pm 5.19 \mathrm{~g}$ weight). Raw fish analyzes were carried out on fresh fish meat without cooking. The procedure for the four experimental groups were described below:

Open roasting (control): The fillets are randomly arranged on the baking tray. No packaging material was used at this stage. The fish was cooked without any material.

Oven bag (Group A): The fillets were first placed in an oven bag (Koroplast, 25x38 cm) and the bag was closed. The bag was then placed on the baking tray, and several holes were drilled in the oven bag with the help of a toothpick.

Baking paper (Group B): The fillets were first placed on an approximately $37 \times 50 \mathrm{~cm}$ sheet of baking paper. The opposite ends of the baking paper are then brought together, and the ends are bent (like a boat). In the meantime, the upper part of the baking paper was pulled together so that the fish were completely covered.

Aluminum foil (Group C): The fillets were packed in the same manner as the baking paper 
group using an approximately $30 \times 50 \mathrm{~cm}$ sheet of aluminum foil. The top of the aluminum foil was closed to cover the fish completely.

All the groups were then cooked in an electrical oven at $180{ }^{\circ} \mathrm{C}$ for $20 \mathrm{~min}$.

\section{Nutritional composition analysis}

After cooking, samples of each group were homogenized in a blender. The crude protein was determined using the Kjeldahl method (AOAC, 1961). Lipids were extracted using the method employed by Bligh and Dyer (1959). The moisture content and crude ash content were determined according to the methods used by Ludorf and Meyer (1973) and AOAC (1984) respectively. Energy value was estimated by the Atwater method (Falch et al., 2010). All measurements were carried out in triplicate.

\section{Amino acid analyses}

The fish sample was weighed (0.1-1 g), placed in $50 \mathrm{ml}$ flask and $20 \mathrm{ml}$ of $\mathrm{HCl}$ was added. The samples were hydrolyzed at $110{ }^{\circ} \mathrm{C}$ for $24 \mathrm{~h}$ (Blackburn, 1968). Following hydrolysis, the hydrolysate was filtered through a filter paper. 0.2 $\mathrm{ml}$ filtrate was evaporated with nitrogen gas at 50 ${ }^{\circ} \mathrm{C} .0 .5 \mathrm{ml}$ filtrate and ACN: MeOH:TEA mixture were derivatization by derivatization solution at $40^{\circ} \mathrm{C}$ for $30 \mathrm{~min}$. The filtrate was evaporated with nitrogen gas at $40^{\circ} \mathrm{C}$ and $5 \mathrm{ml}$ ammonium acetate $(0.02 \mathrm{M})$ was added. The sample was filtered through a filter paper $(0.45 \mu)$ and then injected into the UFLC. Amino acids were separated by SPD-20A, UFLC (Shimadzu, Japan) using a 4x6x150 mm, Agilent, Eclipse X08-C18 column. The detection wavelength was set at UV $254 \mathrm{~nm}$. The amino acids were measured by using available standard amino acid data.

\section{Physical parameters}

Water activity and color analyses were conducted according to AOAC (1980) and Schubring (2003), respectively. The Novasina Lab Swift water activity measurement device and Konica Minolta/CR-A 33a color measuring device was used for water activity and color measurements. Cooking loss was determined according to Barbanti and Pasquini (2005). All measurements were carried out in triplicate.

\section{Sensory Analysis}

Sensory analyzes were performed by 5 experienced academic staff working at the Faculty of Fisheries of Sinop University. Panelists were informed about the subject before sensory analysis. Scorpionfish is a species of fish that can be obtained during the fishing season in Sinop, Turkey. There are no restrictions on fishing.

The scorpionfish samples were cooked in an electrical oven at $180^{\circ} \mathrm{C}$ for $20 \mathrm{~min}$. The sensory attributes of the control group, the oven bag group, the baking paper group, and the aluminum foil group were evaluated following the cooking process. Fish samples from the different treatments were individually served $(20 \mathrm{~g})$ in dishes to each panelist. A hedonic scale was used for evaluation of the appearance, odor, flavor, texture, color, and overall acceptability (Altug and Elmac1, 2005). Sensory analyses were carried out as 2 replications and 2 parallel.

\section{Statistical analysis}

Using the Minitab 17 program experimental data were analyzed using a one-way analysis of variance (ANOVA). For data analysis, mean and standard error were used. The significance level was defined at $\mathrm{P}<0.05$. Statistical calculations for the sensory analyses were carried out using a nonparametric Friedman's test.

\section{RESULTS AND DISCUSSION}

Nutritional and amino acid compositions of scorpionfish meats

The results of the nutritional composition analysis of the groups are shown in Table 1.

The contents of the scorpionfish used in this study showed $16.61 \%$ crude protein, $0.20 \%$ crude fat, $80.62 \%$ moisture, $1.92 \%$ crude ash, and 70.84 Kcal energy. The nutritional composition of the raw fillets is similar to earlier reports on scorpionfish (Ozden and Erkan, 2011; Kaya and Kocatepe, 2014). Significantly higher protein content $(26.18 \pm 0.12)$ was recorded in the control group, followed by $(25.67 \pm 0.06)$ the fish cooked in baking paper, compared with the fish prepared with the other cooking methods $(\mathrm{P}<0.05)$. The oven bag group had the lowest protein content, possibly due to its high moisture content $(\mathrm{P}<$ 
0.05). It was found that the moisture content of cooked scorpionfish (except for the control group) was not significantly affected by the cooking methods $(\mathrm{P}>0.05)$. Tokur (2007) reported that the aluminum foil that was used to cover the rainbow trout (Oncorbynchus mykiss) during baking prevented moisture loss. In contrast, the moisture contents in present study were as follows: oven bag group>baking paper group>aluminum foil group>open roasting (control) group, respectively. Open roasting (control group) may have led to rapid drying of the inner and external layers of the fish meat, resulting in much of the water leaving the fish meat as cooking progressed. This might have been the case because the fish fillets were not too thick. Scorpionfish is known as a lean fish. The fat content of the scorpionfish was increased in all cooking methods in the present study. $(\mathrm{P}<0.05)$.

Table 1. Nutritional composition of the scorpionfish that cooked with different cooking materials

\begin{tabular}{lccccc}
\hline & Raw & Control & A & B & C \\
\hline Crude protein (\%) & $16.61 \pm 0.03^{\mathrm{d}}$ & $26.18 \pm 0.12^{\mathrm{a}}$ & $23.44 \pm 0.15^{\mathrm{c}}$ & $25.67 \pm 0.06^{\mathrm{a}}$ & $24.40 \pm 0.29^{\mathrm{b}}$ \\
Crude fat (\%) & $0.20 \pm 0.01^{\mathrm{d}}$ & $1.57 \pm 0.00^{\mathrm{b}}$ & $1.31 \pm 0.08^{\mathrm{bc}}$ & $1.17 \pm 0.12^{\mathrm{c}}$ & $2.20 \pm 0.01^{\mathrm{a}}$ \\
Moisture (\%) & $80.62 \pm 0.00^{\mathrm{a}}$ & $68.43 \pm 0.10^{\mathrm{c}}$ & $71.59 \pm 0.53^{\mathrm{b}}$ & $70.79 \pm 0.41^{\mathrm{b}}$ & $70.41 \pm 0.14^{\mathrm{b}}$ \\
Crude ash (\%) & $1.92 \pm 0.01^{\mathrm{b}}$ & $2.47 \pm 0.12^{\mathrm{a}}$ & $2.13 \pm 0.01^{\mathrm{ab}}$ & $1.19 \pm 0.11^{\mathrm{c}}$ & $1.74 \pm 0.04^{\mathrm{b}}$ \\
Carbohydrate (\%) & $0.66 \pm 0.01^{\mathrm{a}}$ & $1.35 \pm 0.10^{\mathrm{a}}$ & $1.54 \pm 0.47^{\mathrm{a}}$ & $1.20 \pm 0.24^{\mathrm{a}}$ & $1.27 \pm 0.45^{\mathrm{a}}$ \\
Energy (kcal/100g) & $70.84 \pm 0.00^{\mathrm{c}}$ & $124.25 \pm 0.08^{\mathrm{a}}$ & $111.65 \pm 1.79^{\mathrm{b}}$ & $117.97 \pm 1.80^{\mathrm{ab}}$ & $122.40 \pm 0.72^{\mathrm{a}}$ \\
\hline $\mathrm{n}=3$
\end{tabular}

$\mathrm{n}=3$

Values are shown as mean \pm standard error.

Different letters between groups are statistically significant in the same row $(\mathrm{p}<0.05)(\rightarrow)$

(Control: open roasting, Group A: oven bag, Group B: baking paper, Group C: aluminum foil)

In addition, the amount of crude ash was found to be higher in the control and oven bag groups than in the baking paper and aluminum foil groups. It can be said that the proportional increase was due to water loss. Hoffman and Tlhong (2012) investigated the nutritional composition of guinea fowl (Numida meleagris) meat cooked according to three different methods (baking bag, foil wrap, open roasting). They also found that the open roasting method (control) resulted in a higher protein and ash content compared with the other cooking methods. A total of nineteen kinds of amino acids were identified in the groups. The amino acid compositions of scorpionfish meat that was cooked using different cooking methods are shown in Table 2.

The results show that the main amino acids of raw scorpionfish were glutamic acid, aspartic acid and lysine. The essential amino acids (Arginine, histidine, isoleucine, leucine, lysine, methionine, phenylalanine, threonine, valine) of raw scorpionfish constituted approximately 53.15\% of the total amino acids. In this study, the ratio of essential/non-essential amino acids (E/NE) was observed to be 1.20 in raw scorpionfish meat, and there was no statistical change according to the cooking process. The aspartic acid content decreased with cooking in all groups. On the other hand, the glutamic acid, leucine, lysine, and phenylalanine contents of raw meat increased with cooking, and they were statistically different from the raw meat content. The total amino acid and essential amino acid contents of the control group were the highest. In present study, it is clear that cooking in different packaging changes the essential amino acid content. The World Health Organization (2007) reported the adult daily intake of essential amino acids, leucine, isoleucine, threonine, and methionine should be $0.83 \mathrm{~g} / \mathrm{kg}, 5.9 \mathrm{~g} / 100 \mathrm{~g}, 4.5 \mathrm{~g} / 100 \mathrm{~g}, 3 \mathrm{~g} / 100 \mathrm{~g}, 2.3$ $\mathrm{g} / 100 \mathrm{~g}$, and $1.6 \mathrm{~g} / 100 \mathrm{~g}$, respectively. In present study, it was determined that about $40-49 \%$ of leucine, $76-96 \%$ of lysine, $40-51 \%$ of isoleucine, $64-72 \%$ of threonine, and $61-79 \%$ of methionine content which should be taken daily was provided in $100 \mathrm{~g}$ of different cooked scorpionfish meat. 
Table 2. Amino acid composition of the scorpionfish that cooked with different cooking materials

\begin{tabular}{|c|c|c|c|c|c|}
\hline & Raw & Control & $\mathrm{A}$ & B & $\mathrm{C}$ \\
\hline Alanine & $1.18 \pm 0.00^{\mathrm{d}}$ & $2.20 \pm 0.00^{a}$ & $1.81 \pm 0.02^{\mathrm{c}}$ & $1.75 \pm 0.01^{\mathrm{c}}$ & $1.97 \pm 0.02^{\mathrm{b}}$ \\
\hline Arginine & $1.35 \pm 0.06^{\mathrm{d}}$ & $2.44 \pm 0.01^{\mathrm{a}}$ & $1.98 \pm 0.01^{\mathrm{c}}$ & $2.01 \pm 0.01^{\mathrm{c}}$ & $2.23 \pm 0.01^{\mathrm{b}}$ \\
\hline Aspartic Acid & $2.73 \pm 2.45^{\mathrm{a}}$ & $0.58 \pm 0.02^{\mathrm{b}}$ & $0.47 \pm 0.00^{\mathrm{b}}$ & $0.47 \pm 0.01^{b}$ & $0.57 \pm 0.02^{\mathrm{b}}$ \\
\hline Cysteine & $0.23 \pm 0.01^{\mathrm{a}}$ & $0.27 \pm 0.00^{\mathrm{a}}$ & $0.29 \pm 0.01^{\mathrm{a}}$ & $0.19 \pm 0.06^{\mathrm{a}}$ & $0.31 \pm 0.03^{\mathrm{a}}$ \\
\hline Glutamic Acid & $2.66 \pm 0.02^{c}$ & $4.15 \pm 0.02^{\mathrm{a}}$ & $3.63 \pm 0.00^{\mathrm{b}}$ & $3.75 \pm 0.03^{\mathrm{b}}$ & $4.02 \pm 0.06^{\mathrm{a}}$ \\
\hline Glycine & $0.96 \pm 0.12^{\mathrm{b}}$ & $1.59 \pm 0.09^{a}$ & $1.48 \pm 0.03^{a}$ & $1.50 \pm 0.05^{\mathrm{a}}$ & $1.60 \pm 0.09^{a}$ \\
\hline Histidine & $0.45 \pm 0.04^{c}$ & $0.96 \pm 0.02^{\mathrm{a}}$ & $0.75 \pm 0.02^{\mathrm{b}}$ & $0.76 \pm 0.01^{b}$ & $0.91 \pm 0.02^{\mathrm{a}}$ \\
\hline Isoleucine & $0.87 \pm 0.03^{c}$ & $1.53 \pm 0.00^{\mathrm{a}}$ & $1.22 \pm 0.02^{\mathrm{b}}$ & $1.21 \pm 0.03^{\mathrm{b}}$ & $1.42 \pm 0.03^{\mathrm{a}}$ \\
\hline Leucine & $1.62 \pm 0.00^{\mathrm{d}}$ & $2.91 \pm 0.03^{\mathrm{a}}$ & $2.44 \pm 0.05^{b c}$ & $2.37 \pm 0.08^{c}$ & $2.66 \pm 0.00^{\mathrm{b}}$ \\
\hline Lysine & $2.34 \pm 0.06^{\mathrm{d}}$ & $4.34 \pm 0.07 \mathrm{a}$ & $3.40 \pm 0.05^{c}$ & $3.48 \pm 0.04 c$ & $3.91 \pm 0.04^{\mathrm{b}}$ \\
\hline Methionine & $0.66 \pm 0.01^{c}$ & $1.26 \pm 0.02^{\mathrm{a}}$ & $1.04 \pm 0.06^{\mathrm{b}}$ & $0.97 \pm 0.02^{\mathrm{b}}$ & $1.13 \pm 0.02^{\mathrm{ab}}$ \\
\hline Ornithine & $0.04 \pm 0.00^{\mathrm{a}}$ & $0.05 \pm 0.01^{\mathrm{a}}$ & $0.05 \pm 0.01^{a}$ & $0.06 \pm 0.01^{a}$ & $0.05 \pm 0.00^{\mathrm{a}}$ \\
\hline Phenylalanine & $0.93 \pm 0.01^{\mathrm{d}}$ & $1.59 \pm 0.03^{\mathrm{a}}$ & $1.29 \pm 0.02^{\mathrm{c}}$ & $1.27 \pm 0.02^{\mathrm{c}}$ & $1.45 \pm 0.01^{\mathrm{b}}$ \\
\hline Proline & $0.78 \pm 0.00^{\mathrm{d}}$ & $1.35 \pm 0.00^{a}$ & $1.13 \pm 0.01^{c}$ & $1.15 \pm 0.01^{c}$ & $1.27 \pm 0.01^{b}$ \\
\hline Serine & $0.90 \pm 0.00^{c}$ & $1.59 \pm 0.03^{\mathrm{a}}$ & $1.34 \pm 0.01^{b}$ & $1.29 \pm 0.04^{\mathrm{b}}$ & $1.58 \pm 0.02^{\mathrm{a}}$ \\
\hline Threonine & $0.99 \pm 0.03^{b}$ & $1.63 \pm 0.03^{\mathrm{a}}$ & $1.58 \pm 0.03^{\mathrm{a}}$ & $1.48 \pm 0.02^{\mathrm{a}}$ & $1.65 \pm 0.06^{\mathrm{a}}$ \\
\hline Tyrosine & $0.79 \pm 0.00^{\mathrm{b}}$ & $1.23 \pm 0.05^{\mathrm{a}}$ & $1.20 \pm 0.03^{a}$ & $1.08 \pm 0.02^{\mathrm{a}}$ & $1.24 \pm 0.06^{a}$ \\
\hline Valine & $1.05 \pm 0.01^{\mathrm{e}}$ & $1.91 \pm 0.03^{\mathrm{a}}$ & $1.59 \pm 0.02^{c}$ & $1.47 \pm 0.01^{\mathrm{d}}$ & $1.76 \pm 0.01^{\mathrm{b}}$ \\
\hline Taurine & $0.24 \pm 0.01^{b}$ & $0.53 \pm 0.04^{\mathrm{a}}$ & $0.29 \pm 0.02^{\mathrm{b}}$ & $0.31 \pm 0.02^{\mathrm{b}}$ & $0.32 \pm 0.03^{\mathrm{b}}$ \\
\hline Total amino acids & $20.75 \pm 2.38^{b}$ & $32.12 \pm 0.05^{\mathrm{a}}$ & $26.99 \pm 0.13^{\mathrm{a}}$ & $26.55 \pm 0.03^{\mathrm{ab}}$ & $30.04 \pm 0.32^{\mathrm{a}}$ \\
\hline Total essential amino acids & $11.03 \pm 0.04^{\mathrm{e}}$ & $19.79 \pm 0.06^{\mathrm{a}}$ & $16.50 \pm 0.03^{c}$ & $16.08 \pm 0.05^{\mathrm{d}}$ & $18.36 \pm 0.08^{\mathrm{b}}$ \\
\hline Total non-essential amino acids & $9.73 \pm 2.34^{a}$ & $12.32 \pm 0.00^{\mathrm{a}}$ & $10.49 \pm 0.10^{\mathrm{a}}$ & $10.47 \pm 0.02^{\mathrm{a}}$ & $11.68 \pm 0.24^{\mathrm{a}}$ \\
\hline $\mathrm{E} / \mathrm{NE}$ & $1.20 \pm 0.29^{a}$ & $1.61 \pm 0.01^{\mathrm{a}}$ & $1.57 \pm 0.01^{\mathrm{a}}$ & $1.54 \pm 0.01^{\mathrm{a}}$ & $1.57 \pm 0.03^{\mathrm{a}}$ \\
\hline Sweet amino acids & $5.70 \pm 0.10^{c}$ & $9.53 \pm 0.05^{\mathrm{a}}$ & $8.26 \pm 0.07^{b}$ & $8.29 \pm 0.07 \mathrm{~b}$ & $9.16 \pm 0.16^{a}$ \\
\hline Bitter amino acids & $5.72 \pm 0.06^{\mathrm{d}}$ & $10.59 \pm 0.04^{a}$ & $8.47 \pm 0.04 c$ & $8.49 \pm 0.05^{c}$ & $9.63 \pm 0.01^{b}$ \\
\hline
\end{tabular}

Values are shown as mean \pm standard error.

Different letters between groups are statistically significant in the same row $(p<0.05)(\rightarrow)$ (Control: open roasting, Group A: oven bag, Group B: baking paper, Group C: aluminum foil)

Seafood is one of the most aromatic foods. It has a particularly delicious and different aroma from other foods, especially because it contains a high proportion of glutamic acid. The glutamic acid content of the groups cooked in an oven and cooked in aluminum foil was statistically similar and high. Yamaguchi and Ninomiya (2000) and Zhang et al., (2013) reported that glutamic acid and aspartic acid sodium salts are the reason that umami and other amino acids are reported to have sweet, bitter, or neutral flavor characteristics (Beluhan and Ranogajec, 2011; Mau et al., 1998). Glutamate, an element of protein, is the most plenteous amino acid in the universe. Meat, milk, fish, and many vegetables can naturally contain glutamate. It has an influential umami taste. It is essential for human nutrition (Ninomiya, 2002). In particular, glutamic acid including di-tri peptides has been of specific significance because they are related to the alone flavor of umami 
(Dang et al., 2015). For example, Ninomiya (2002) reported that the unique flavor of some crabs and scallops is due to a combination of organic amino acids in which alanine, glycine, glutamate, and aspartate are essential elements. In present study, the total aspartic acid and glutamic acid contents of the groups were Control $>$ Group C $>$ Group B $>$ Group A, respectively. In general, there is an inverse relationship between cooking in different packaging materials and the umami flavor.

The bitter and sweet amino acid profiles of each of the groups are listed in Table 2 . These amino acids are total sweet amino acids $(\Sigma$ Sweet AA) including Glutamic acid (Glu), Serine (Ser), Glycine (Gly), and Alanine (Ala); total bitter amino acids ( $\Sigma$ Bitter AA) including Histidine (His), Arginine (Arg), Methionine (Met), Phenylalanine (Phe), Lysine (Lys) according to Schiffman (1975). The maximum bitter amino acids were found in the control group and the packaging materials affected the bitter amino acid contents. The sweet amino acids contents of the control and the aluminum foil groups were statistically similar and higher than that of the others.

\section{Physical parameters}

The physical analyses result of the scorpionfish that was cooked using different cooking materials is presented in Table 3 .

Table 3. Physical analyses result of the scorpionfish that cooked with different cooking materials

\begin{tabular}{lccccc}
\hline & Raw & Control & A & B & C \\
\hline Water activity (aw) & $0.96 \pm 0.00^{\mathrm{a}}$ & $0.96 \pm 0.00^{\mathrm{a}}$ & $0.96 \pm 0.00^{\mathrm{a}}$ & $0.96 \pm 0.00^{\mathrm{a}}$ & $0.96 \pm 0.00^{\mathrm{a}}$ \\
L & $56.80 \pm 0.35^{\mathrm{d}}$ & $78.91 \pm 1.39^{\mathrm{ab}}$ & $72.61 \pm 0.79^{\mathrm{bc}}$ & $69.11 \pm 0.04^{\mathrm{c}}$ & $83.79 \pm 2.37^{\mathrm{a}}$ \\
$\mathrm{a}$ & $-0.54 \pm 0.03^{\mathrm{bc}}$ & $-0.83 \pm 0.06^{\mathrm{c}}$ & $-1.10 \pm 0.10^{\mathrm{c}}$ & $0.24 \pm 0.09^{\mathrm{a}}$ & $-0.12 \pm 0.23^{\mathrm{ab}}$ \\
$\mathrm{b}$ & $4.39 \pm 0.37^{\mathrm{c}}$ & $13.18 \pm 0.52^{\mathrm{ab}}$ & $11.82 \pm 0.03^{\mathrm{b}}$ & $12.83 \pm 0.06^{\mathrm{ab}}$ & $14.34 \pm 0.48^{\mathrm{a}}$ \\
Cooking loss (\%) & - & $44.78 \pm 0.00^{\mathrm{a}}$ & $37.82 \pm 0.23^{\mathrm{b}}$ & $37.96 \pm 0.00^{\mathrm{b}}$ & $38.07 \pm 0.05^{\mathrm{b}}$ \\
\hline
\end{tabular}

$\mathrm{n}=3$

Values are shown as mean \pm standard error.

Different letters between groups are statistically significant in the same row $(\mathrm{p}<0.05)(\rightarrow)$ (Control: open roasting, Group A: oven bag, Group B: baking paper, Group C: aluminum foil)

There was no statistically significant difference between the water activity values of raw and cooked scorpionfish samples. Bainy et al., (2015) reported similar results for raw, baked, and grilled fish burgers.

Consumers frequently evaluate the original quality of a product by its color and visual aspect, with color serving as a clue as to how well the food is cooked. The color changes during cooking, have critical importance, not only on the product quality but also on the safety (Matsuda et al., 2013). In the Commission Internationale de l'Eclairage, (CIE) Lab color system, L* indicates lightness on a 0 to 100 scale from black to white; $\mathrm{a} *$ indicates $(+)$ red or $(-)$ green; and $\mathrm{b} *$ indicates $(+)$ yellow or $(-)$ blue (CIE, 1995).
In the present study, the $\mathrm{L}$ and $\mathrm{b}$ values of the raw scorpionfish sample were increased after cooking using all methods $(\mathrm{P}<0.05)$. Cardinal et al., (2011) reported similar results for raw and cooked sea bream. The $a^{*}$ values were found to be highest in the baking paper group.

The yellowness $\left(b^{*}\right)$ value increased after the cooking of raw scorpionfish. Similar results have been reported by Bainy et al., (2015). In general, a browning reaction was not observed in samples involving the oven bag, the baking paper, and the aluminum foil in that the samples were wrapped in packaging material. Although visual browning is observed in the control group, it is thought that in particular $a^{*}$ values may be affected because color analyzes are made from homogenized samples. The purpose of using homogenized samples is to increase visual stability. Studies in 
which color measurement with homogenized samples are available in the literature (Çorapc1 et al. 2020).

The percentage weight losses in terms of the cooking processes varied with the cooking materials. The least percentage loss was found in the case of oven bag cooking. The scorpionfish cooked using the oven bag, the baking paper and the aluminum foil had similar weight losses of $37.82,37.96$, and $38.07 \%$. The weight loss of the open roasting (control) scorpionfish samples was significantly higher compared with the other cooking methods (44.78\%).

Salmon et al., (2006) reported the cooking weight loss for pan-fried whole red snapper with skin as
$20.9 \%$. In another study, Semedo Tavares et al., (2018) reported that the cooking weight loss for baked hairtail (Thichiurus lepturus) fillets were $49.6 \%$. $\left(220^{\circ} \mathrm{C}-20 \mathrm{~min}\right)$. These values were different from the values in present study. Of course, cooking time, cooking method, and type of fish are important parameters in terms of this difference. It was also revealed that the use of materials such as baking paper, aluminum foil, and oven bags during cooking may reduce the cooking weight loss.

\section{Sensory Analysis}

The sensory scores of cooked scorpionfish meats were as shown in Figure 1.
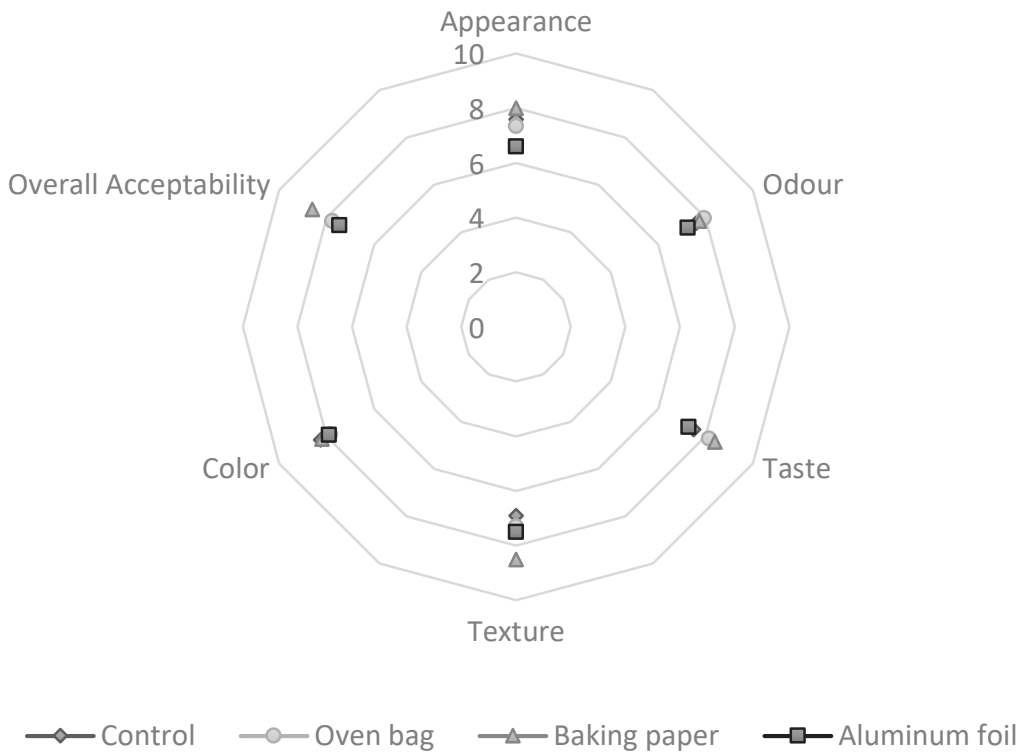

Figure 1. Sensory analysis results of the scorpionfish that cooked with different cooking materials Hedonic scale on a 1 - to 9-point scale: $1=$ dislike extremely, $2=$ dislike very much, $3=$ dislike moderately, $4=$ dislike slightly, $5=$ neither like nor dislike, $6=$ like slightly, $7=$ like moderately, $8=$ like very much, and $9=$ like extremely.

The volatile components play an important role in the flavor of cooked fish products. Therefore, the quantity and quality of these compounds are important criteria (Kawai, 1996).

In the present study, the highest appearance, flavor, texture, and overall acceptability scores were determined to exist in scorpionfish that was cooked using baking paper. These values were found to be $8.00 \pm 0.08,8.40 \pm 0.10,8.50 \pm 0.10$ and $8.60 \pm 0.10$ respectively. The highest odor scores were found in the fish cooked in the oven bag (7.95 \pm 0.24$)$, while the highest color scores were found in the open roasting (control) group 
(8.25 \pm 0.10$)$. According to Friedman's test, the appearance, flavor, and texture values of the scorpionfish that was cooked with different cooking materials were found to be significantly different from each other. In addition, the odor, color, and overall acceptability scores were found to be statistically non-significant.

The effect of cooking materials on the product can directly affect consumer preferences. Therefore, the cooking materials that used in this study are important for future studies. According to the results of the sensory analysis, the method of cooking using baking paper can be said to be the most preferable method for this fish. However, the fact that the oven bag did not give out any odor had a positive effect on the odor scores. In addition, it is not surprising that the color values in the open roasting group are high. It can be said that this situation is related to the browning reaction that occurs on the product's surface during cooking. The flavor values in terms of groups were group $\mathrm{B}>$ group $\mathrm{A}>$ control group>group C. However, the sum of glutamic acid and aspartic acids used in the evaluation of the umami flavor of the groups was as follows: Control $>$ group $\mathrm{C}>$ group $\mathrm{B}>$ group $\mathrm{A}$. In particular, the glutamic acid and aspartic acid contents of the control group were higher than in Group B (oven bag). This result suggests that sensory evaluation should be supported in further studies by umami flavor analysis and the use of an electronic nose.

\section{CONCLUSIONS}

As a result, it has been observed that cooking materials such as oven bag, baking paper and aluminum foil have a significant effect on nutrient and amino acid compositions. The aromatic amino acid content of the control group was higher than the other groups. Water activity values did not show any difference in raw fish and between groups. It was observed that the L*, a* and $b^{*}$ values were affected by the cooking materials. However, there was no statistical difference between the cooking loss values.

It can be said that the scorpionfish is a delicious fish with high glutamic acid and aspartic acid content important in umami flavor. Although the fish is cooked using many different cooking materials, it is obvious that cooking by open roasting (control) is the most nutritious. However, the best group in terms of the sensory evaluation was determined to be the group cooking using baking paper.

\section{CONFLICT OF INTEREST}

The author declares that there are not any competing interests.

\section{REFERENCES}

Altug, T., Elmaci, Y. (2005). Sensory Evaluation in Foods. Izmir: Meta Publications, p. 105.

AOAC. (1961). Officials Methods of Analysis. Association of Official Analytical Chemists. Washington. D.C.

AOAC. (1980). Association of Official Analytical Chemists, 13th ed. Water Activity: 32.004-32.009.

AOAC. (1984). Officials Methods of Analysis. Association of Official Analytical Chemists. Washington. D.C.

Bainy, E.M., Bertan, L.C., Corazza, M.L., Lenzi, M.K. (2015). Effect of grilling and baking on physicochemical and textural properties of tilapia (Oreochromis niloticus) fish burger. J Food Sci Technol. 52(8):5111-5119, doi: 10.1007/s13197-014-16043

Barbanti, D., Pasquini, M. (2005). Influence of cooking conditions on cooking loss and tenderness of raw and marinated chicken breast meat. LWT-Food Sci Technol. 38(8):895-901, doi:10.1016/j.lwt.2004.08.017

Beluhan, S., Ranogajec, A. (2011). Chemical composition and non-volatile components of croatian wild edible mushrooms. Food Chem. 124(3):1076-1082, doi: 10.1016/j.foodchem. 2010.07 .081

Blackburn, S. (1968). Amino Acid Determination; Methods and Techniques. New York: M. Dekker.

Bligh, E.G., Dyer, W.J. (1959). A rapid method of total lipid extraction and purification. Can J Biochem Phys. 37(8): 911-917. doi: 10.1139/o59099 
Cardinal, M., Cornet, J., Donnay-Moreno, C., Gouygou, J.P., Berge, J.P., Rocha, E., Soares, S., Escorcio, C., Borges, P., Valente, L.M.P. (2011). Seasonal variation of physical, chemical and sensory characteristics of sea bream (Sparus aurata) reared under intensive conditions in Southern Europe. Food Control, 22(3-4):574-585, doi:10.1016/j.foodcont.2010.10.007

Cheung, L.K.Y., Tomita, H., Takemori, T. (2016). Mechanisms of docosahexaenoic and eicosapentaenoic acid loss from pacific saury and comparison of their retention rates after various cooking methods. J Food Sci. 81(8):1899-1907, doi:10.1111/1750-3841.13367

CIE, (1995). Industrial colour-difference evaluation. CIE Publication 116. Vienna, Austria: Central Bureau of the CIE.

Corapci, B., Kostekli, B., Eyuboğlu, A., Kocatepe, D. (2020). The effect of different application methods of sumac (Rhus coriaria) and tarragon (Artemisia dracunculus) on some quality properties of marinated sea bream (Sparus aurata L., 1758). J. Food Process. Preserv. 44, (10), doi:10. $1111 /$ jfpp.14751

Dang, Y., Gao, X., Ma, F., Wu, X. (2015). Comparison of umami taste peptides in watersoluble extractions of jinhua and parma hams. LWT-Food Sci Technol. 60(2):1179-1186, doi:10.1016/j.lwt.2014.09.014

Falch, E., Overrien, I., Solberg, C., Slizyte, R. (2010). Composition and Calories. In: Nollet, L. M. L. - Toldrá, F. (Eds): Seafood and Seafood Product Analysis. Part III (Chapter 16), New York: CRC Press. pp 257-288.

Friedman, M. (1996). Nutritional value of proteins from different food sources. J. Agric. Food Chem. 44(1):6-29, doi:10.1021/jf9400167

Hoffman, L.C., Tlhong, T.M. (2012). Proximate and fatty acid composition and cholesterol content of different cuts of guinea fowl meat as affected by cooking method. I Sci Food Agric. 92(13): 2587-2593, doi: 10.1002/jsfa.5682

Kawai, T. (1996). Fish Flavor. Crit. Rev. Food Sci. Nutr. 36(3):257-298.
Kaya, Y., Kocatepe, D. (2014). Chemical composition and nutritional quality of scorpion fish (Scorpaena porcus, linnaeus 1758) muscle. Indian J. Anim. Res. 48 (1): 83-87, doi:10.5958/j.09760555.48.1.018

Love, M.S., Axell, B., Morris, P., Collins, R., Brooks, A. (1987). Life history and fishery of the california scorpionfish, scorpaena guttata, within the southern california bight. Fish Bull. 85(1):99-116.

Ludorff, W., Meyer, V. (1973). Fishe und fisherzeuge. Z.Auflage. Verlag Paul Parey. In, Berlin und Hamburg: 209-210.

Matsuda, H., Llave, Y., Fukuoka, M., Sakai, N. (2013). Color changes in fish during grilling influences of heat transfer and heating medium on browning color. J Food Eng. 116(1):130-137, doi:10.1016/j.jfoodeng.2012.11.027

Mau, J.L., Lin, Y.P., Chen, P.T., Wu, Y.H., Peng, J.T. (1998). Flavor compounds in king oyster mushrooms Pleurotus eryngii. J Agric Food Chem. 46(11):4587-4591, doi:10.1021/jf980508

Moradi, Y., Bakar, J., Motalebi, A.A., Syed Muhamad, S.H., Man, Y.C. (2011). A review on fish lipid: composition and changes during cooking methods. J. Aquat. Food Prod. Technol. 20:379-390, doi:10.1080/10498850.2011.576449

Ninomiya, K. (2002). Umami: A Universal Taste. Food Rev Int. 18(1):23-38.

Ozden, O., Erkan, N. (2011). A preliminary study of amino acid and mineral profiles of important and estimable 21 seafood species. Br Food J. 113(4):457-469, doi:10.1108/00070701111123943

Salmon, C.P., Knize, M.G., Felton, J.S., Zhao, B., Seow, A. (2006). Heterocyclic aromatic amines in domestically prepared chicken and fish from singapore chinese households. Food Chem. Toxicol. 44(4):484-492, doi:10.1016/j.fct.2005.08.022

Schiffman, S.S. (1975). Taste of nutrients: amino acids, vitamins, and fatty acids. Percep. Phsch. 17(2):140-146.

Schubring, R. (2003). Colour measurement for the determination of the freshness of fish. In: JB. Luten, J. Oehlenschlager and G. Olafsdottir, 
Editors, Quality of Fish from Catch to Consumer: Labelling, Monitoring and Traceability, Wageningen Academic Publishers, The Netherlands, pp. 251-263.

Semedo Tavares, W.P., Dong, S., Yang, Y., Zeng, M., Zhao, Y. (2018). Influence of cooking methods on protein modification and in vitro digestibility of hairtail (Thichiurus lepturus) fillets. Food Sci. Technol. 96:476-481, doi:10.1016/ j.lwt.2018.06.006

Tokur, B. (2007). The effect of different cooking methods on proximate composition and lipid quality of rainbow trout (Oncorbynchus mykiss). Int. J Food Sci Technol. 42(7):874-879, doi:10.1111/ j.1365-2621.2006.01298.x

TUIK. (2019). Fisheries Statistics. Turkey Statistical Institute. http://tuik.gov.tr/ PreTablo.do?alt_id=1005.

Turk Culha, S., Yabanli, M., Baki, B., Yozukmaz, A. (2016). Heavy metals in tissues of scorpionfish (Scorpaena porcus) caught from Black Sea (Turkey) and potential risks to human health. Environ Sci
Pollut Res. 23(20):20882-20892, doi:10.1007/ s11356-016-7337-2

Uran, H., Gökoglu, N. (2014). Effects of cooking methods and temperatures on nutritional and quality characteristics of anchovy (Engraulis encrasicholus). J Food Sci Technol. 51(4):722-728, doi:10.1007/s13197-011-0551-5

WHO. (2007). Protein and Amino Acid Requirements in Human Nutrition. Report of a Joint WHO/FAO/UNU Expert Consultation. WHO Technical Report Series. No: 935.

Yamaguchi, S., Ninomiya, K. (2000). Umami and food palatability. J Nutr. 130 (4):921-926, doi:10.1093/jn/130.4.921s

Zhang, Y., Venkitasamy, C., Pan, Z., Wang, W. (2013). Recent developments on umami ingredients of edible mushrooms-A review. Trends Food Sci Technol. 33(2):78-92, doi:10.1016/j.tifs.2013.08.002 